\title{
Prevalence of ideation and attempted suicide among users of a psychosocial care center
}

\author{
Prevalência de ideação e tentativa de suicídio entre usuários \\ de um centro de atenção psicossocial \\ La prevalencia de la ideación y el intento de suicidio entre los \\ usuarios de un centro de atención psicossocial
}

\section{Luciane Prado Kantorski ${ }^{\mathrm{a}}$ \\ Ariane da Cruz Guedes ${ }^{a}$ \\ Camila Irigonhé Ramos ${ }^{\mathrm{a}}$ \\ Carlos Alberto dos Santos Treichel ${ }^{\mathrm{b}}$ \\ Dariane Lima Portela ${ }^{a}$ \\ Janaína Quinzen Willricha \\ Vanda Maria da Rosa Jardima \\ Vinícius Boldt dos Santos ${ }^{\mathrm{a}}$}

How to cite this article:

Kantorski LP, Guedes AC, Ramos Cl, Treichel CAS, Portela DL, Willrich JQ, Jardim VMR, Santos VB. Prevalence of ideation and attempted suicide among users of a psychosocial care center. Rev Gaúcha Enferm. 2021;42:e20190505. doi: https://doi.org/10.1590/19831447.2021.20190505
Universidade Federal de Pelotas (UFPel), Faculdade de Enfermagem. Departamento de Enfermagem em Saúde Coletiva. Pelotas, Rio Grande do Sul, Brasil.

- Universidade Estadual de Campinas (UNICAMP), Faculdade de Ciências Médicas. Departamento de Saúde Coletiva. Campinas, Săo Paulo, Brasil.

\section{ABSTRACT}

Objective: This study aims at identifying and characterizing the prevalence of suicidal ideation and attempted suicide among users of a Psychosocial Care Center in the municipality of Pelotas (RS).

Method: Transversal study, documentary based study in 389 active medical records. Data collection were carried out between September 2017 and May 2018. Data were digitated in the software Microsoft Excel and afterwards converted for the statistical Stata 11 Software. Results: The prevalence of ideation and attempted suicide was $48,1 \%$ and $33,4 \%$, respectively. Significant differences were observed in relation to hearing voices $(p=<0,001)$ and history of violence $(p=<0,001)$. Users who heard voices presented prevalence of suicidal ideation corresponding to $58,1 \%$. Among those users who have reported suicidal ideation, the prevalence of attempt was $57,7 \%$, while the users without report of ideation, the attempts were prevalent in $10,9 \%(p=<0.001)$.

Conclusions: The users presented a significant prevalence of ideation and attempted suicide.

Keywords: Mental health. Community mental health services. Suicidal ideation. Suicide, attempt. Suicide.

\section{RESUMO}

Objetivo: Identificar e caracterizar a prevalência de ideação e tentativa de suicídio entre usuários de um Centro de Atenção Psicossocial do município de Pelotas (RS).

Método: Estudo transversal, de base documental, em 389 prontuários de usuários ativos. A coleta de dados ocorreu entre setembro de 2017 e maio de 2018. Os dados foram digitados no software Microsoft Excel e posteriormente convertidos para o pacote estatístico Stata 11. Resultados: A prevalência de ideação e tentativa de suicídio foi de $48,1 \%$ e 33,4\%, respectivamente. Foram observadas diferenças significativas em relação à escuta de vozes ( $p=<0,001)$ e histórico de violência $(p=<0,001)$. Usuários que ouviam vozes apresentaram prevalência de ideação suicida correspondente a 58,1\%. Entre aqueles usuários que haviam relatado ideação suicida, a prevalência de tentativa foi de $57,7 \%$, enquanto, em usuários sem relato de ideação, as tentativas foram prevalentes em 10,9\% ( $p=<0.001)$.

Conclusões: Os usuários apresentaram uma prevalência significativa de ideação e tentativa de suicídio.

Palavras-chave: Saúde mental. Serviços comunitários de saúde mental. Ideação suicida. Tentativa de suicídio. Suicídio.

\section{RESUMEN}

Objetivo: Identificar y caracterizar la prevalencia de ideación y intento de suicidio entre usuarios de un Centro de Atención Psicosocial delmunicipio de Pelotas (RS)

Método: Estudio transversal, de base documental en 389 prontuarios de usuarios activos. La colecta de datos ocurrió entre setiembre de 2017 y mayo de 2018. Los datos fueron digitados en el software Microsoft Excel y posteriormente convertidos para el paquete estadístico Stata 11.

Resultados: La prevalencia de ideación y intento de suicidio fue 48,1\% y 33,4\%, respectivamente. Fueron observadas diferencias significativas en relación a la audición de voces $(p=<0,001)$ e histórico de violencia $(p=<0,001)$. Usuarios que escucharon voces presentaron prevalencia de ideación suicida correspondiente a 58,1\%. Entre usuarios que habían relatado la ideación suicida, la prevalencia de intento fue de $57,7 \%$, mientras en usuarios sin relato de ideación, los intentos fueron prevalentes en 10,9\% ( $p=<0.001)$. Conclusiones: Los usuarios presentaron una importante prevalencia de ideación e intento de suicidio.

Palabras clave: Salud mental. Servicios comunitarios de salud mental. Ideación suicida. Intento de suicidio. Suicidio. 


\section{口INTRODUCTION}

A very complex set of factors is implicated in the occurrence of suicides, defined as a violence provoked against oneself in which the author knows and desires the result or also an intentional death, seeking to end his own life. Suicide is a phenomenon that carries taboos and controversial opinions in society in general. It is one of the leading causes of death in the world, with approximately one million deaths per year and an annual global age-standardized suicide rate of 8.0 per 100,000 among women and 15.0 per 100,000 among men. This data brings a high probability of underreporting, considering the complexity of the topic, since, in some countries, it is considered illegal and in so many others altered records are identified, being accounted for as an accident or other causes ${ }^{(1)}$.

The growing increase in suicide numbers in Brazil corroborates the above-mentioned trend, making it the third leading cause of death from external factors in the country (6.8\%), surpassed only by homicides (36.4\%) and traffic accident (29.3\%). It should be noted that this number can be much higher, once there are cases of underreporting due to the stigma and taboo related to suicide and also situations in which deaths are typified as other causes of death ${ }^{(1)}$.

In Brazil, the profile of individuals who commit suicide varies according to education, color, age, gender, among others, since it can be understood as a complex phenomenon with multidimensionality resulting from a coexistence of interconnected factors, such as environment, religion, society, physiology, genetics and biology, being the target of prejudice and stigma in many societies. The pain, the compromise of mental health and the suffering that are linked to the act of attempting against one's own life are something that should not be left aside by professionals working in health services and even by society in genera ${ }^{(2-3)}$.

Studies have been carried out to identify risk factors for suicide and serving as a foundation for patterns, aiming to explain the phenomenon. It has been created, in view of the great impact that suicide has on public health issues and the increase in incidences in the country, the National Suicide Prevention Plan, in which measures aimed at the general population and the formation of risk groups, using the studies in the area as a base ${ }^{(2,4)}$. However, because it is a human phenomenon, every suicidal act is permeated with subjectivity and individuality, being necessary to give due attention to the individual experience to understand the risk factors and identify what can be standardized in the debate ${ }^{(5)}$.

Although there is this advance and the effort in relation to public policies aimed at confront and prevent suicide, it remains a major challenge for health professionals to characterize and identify the prevalence of ideation and attempts in order to help prevent it ${ }^{(4)}$. In view of this fact, it becomes relevant to know the characteristics of the individuals who actually commit the attempt or who actually consume the act of suicide so that new strategies are created to avoid the consummation and assist in the treatment of those who attempted suicide(6).

Suicide should not be generalized to correspond, in a simplistic way, to social problems and sadness in life, such as divorce, unemployment, death of loved ones, among others. It is known that suicide occurs in different social groups, suffering or not, from some mental disorder. However, it is relevant to break with the stigma that the mental health user is a potential suicidal, being this a dangerous generalization ${ }^{(6-7)}$.

Based on this information and looking to verify similarities and differences between the suicidal behavior of society in general and users of mental health services, this article aims to identify and characterize the prevalence of ideation and attempted suicide among users of a Psychosocial Care Center in the municipality of Pelotas (RS).

\section{METHODOLOGY}

This is a cross-sectional, documentary study, conducted from the study of medical records of users of a Psychosocial Care Center in the municipality of Pelotas-RS. It is an excerpt from the research"Voice Listeners - new approaches in mental health", which, among other issues, analyzed the profile and occurrence of phenomena such as listening to voices, exposure to violence, in addition to the therapeutic offers received and other outcomes of interest in evaluating the care provided to users. Data collection took place between September 2017 and May 2018 and included all active users in the service during this period. Thus, after surveying the lists of users at the service, the medical records of 389 users were accessed.

The inclusion criteria were to have an active medical record. The verification of the inclusion criteria was carried out by the service workers (nurses and psychologists), who considered active users who had not abandoned the treatment, not missing the service for care in the last three appointments. There were no exclusion criteria.

For data collection, it was used a form designed for the research purposes, composed by objective questions with options for closed and open answers, filled in by previously trained collectors, based on the information available in the medical records. 
In this study, whose outcomes were suicidal ideation and attempted suicide, the collectors were instructed to identify, in the medical records, the presence of a thought report of a self-inflicted action that results in their death or non-fatal self-injurious behavior, with evidence, implicit or explicit, that the person intended to die. From the complete reading of the medical record, the collectors should fill out two questions, one for each situation, with the option of yes and no answers.

It was used, as independent variables, information related to the users' gender (female; male), age (18 to 30 years; 31 to 40 years; 41 to 50 years; 51 to 60 years; 61 years or more), marital status (single; with partner; separated or widowed), schooling (zero to four years of study; five to eight years of study; nine years of study or more), source of income (paid work; family income; aid or benefits), diagnosis (schizophrenia; bipolar affective disorder; depression; mental retardation; other neurotic disorders; other unspecified disorders), hearing voices (absent; present), history of violence (absent; present).

The data were entered into Microsoft Excel software and later converted to the Stata 11 statistical package (Stata Corp., College Station, United States) where the analysis were conducted. Inconsistencies in the data were assessed and corrected when necessary.

Initially, descriptive statistics were used through which the means for numerical variables were calculated, as well as their respective standard deviations, in addition for calculating the prevalence of each strata of the studied variables. For conducting the hypothesis tests, in the case of categorical variables, the chi-square test was used to identify whether there was an association between the independent variables, arranged in line, and the outcome variable, arranged in the column in a contingency table built from sample data. The null hypothesis was that the variables were not associated and the alternative hypothesis that the variables were associated. Statistical significance was defined as a $p$-value $<0.05$. The calculations were performed based on valid data, as missing data (missings) were excluded from the analysis.

The research that originated the study was submitted and approved under the statement number 2,201,138 by the Ethics and Research Committee with human beings of the Faculty of Medicine of the Universidade Federal de Pelotas. The obtention of data was released and supervised by the studied service and its realization took place in compliance with the Brazilian rules and guidelines for the regulation of research involving human beings - Resolution No. 466/2012, guaranteeing the subjects' anonymity.

\section{RESULTS}

Data were collected about 389 users, being $63 \%$ female. The average age was 47.7 years (SD $=12.5)$, with a range from 19 to 86 years. Among the users studied, 59.6\% had up to four years of study, while $19.9 \%$ had studied between five and eight years and $22.5 \%$, nine years or more. As for the source of income, $17.4 \%$ were in a paid work; $22.1 \%$ depended on family income and $60.5 \%$ received some aid or benefit paid by the State, with $31.6 \%$ of users being single, $40.7 \%$ having a partner and $27.6 \%$ were widowed or divorced. The most frequent diagnosis was depression (36.6\% $n=133)$, followed by schizophrenia $(25.1 \% \mathrm{n}=91)$, mental retardation $(14.33 \%$ $n=52)$, bipolar affective disorder $(10.5 \% n=38)$, other neurotic disorders $(8.3 \% \mathrm{n}=30)$ and other unspecified disorders $(5.2 \% n=19)$.

The prevalence of suicidal ideation was $48.1 \%$ (Cl: 43.1 53.0) $(n=187)$ and from attempted suicide was $33.4 \%$ (Cl: 28.9-38.2) $(n=130)$. The table 1 shows the proportion found for each of the outcomes according to the studied characteristics.

The prevalence of suicidal ideation showed statistically significant differences between men and women $(p=0.010)$. While the prevalence observed among men was $39.6 \%$, among women, the prevalence was $53.1 \%$. Regarding the age and marital status of users, although there were no statistically significant differences between the strata, the highest prevalence was observed in individuals between 41 and 50 years old $(60.6 \%)$ and those who had been divorced or were widowed $(56,7 \%)$.

There were also statistically significant differences between users in terms of schooling $(p=0.044)$ and source of income ( $p=0.041$ ). Individuals with less education were those with the lowest prevalence of suicidal ideation (39.3\%) when compared to the others. As for the source of income, individuals who had a paid work were those who had most suicidal ideation (66.7\%).

Among the diagnosis, it was also possible to observe statistically significant differences $(p=<0.001)$. The variation between prevalence was $23.1 \%$ among users with mental retardation and $73.7 \%$ among users with bipolar affective disorder. Also, significant differences were observed in relation to hearing voices $(p=<0.001)$ and history of violence $(p=<0.001)$. Users who heard voices had a prevalence of suicidal ideation corresponding to $58.1 \%$, while among those who did not report this phenomenon, this prevalence was $39.4 \%$. With regard to the history of violence, users who had reported exposure to such a situation had a prevalence of 62.7\%, while users who did not report having been exposed to violence corresponded to a prevalence of $41.1 \%$. 
Table 1 - Prevalence of suicidal ideation and attempted suicide among users of a CAPS in the city of Pelotas (RS) according to strata of the selected variables for the study $(\mathrm{N}=389)$

\begin{tabular}{ccccccc} 
& \multicolumn{3}{c}{ Ideation } & \multicolumn{3}{c}{ Attempt } \\
\cline { 3 - 7 } & $n$ & & $(\%)$ & $\mathbf{p}^{*}$ & $(\%)$ & $\mathbf{p}^{*}$
\end{tabular}

\section{Gender}

Male

144

$39.6 \%$

0.010

$25 \%$

0.007

Female

245

$53.1 \%$

$38.4 \%$

Age

18 to 30 years

42

$40.5 \%$

0.064

$28.6 \%$

0.376

31 to 40 years

59

$45.8 \%$

$28.8 \%$

41 to 50 years

104

$60.6 \%$

$41.3 \%$

51 to 60 years

122

$45.1 \%$

$31.1 \%$

61 years or more

55

$41.8 \%$

$32.7 \%$

Marital status

Single

$40.5 \%$

0.061

$21.6 \%$

0.002

With partner

143

$50.3 \%$

$36.4 \%$

Separated or widowed

97

$56.7 \%$

$44.3 \%$

\section{Schooling}

0 to 4 years of study

140

$39.3 \%$

0.044

$34.3 \%$

0.929

5 to 8 years of study

42

$57.1 \%$

$35.7 \%$

9 years of study or more

53

$54.7 \%$

$32.1 \%$

\section{Source of income}

Paid work

Family income

Aid or benefits

\section{Diagnosis}

Schizophrenia

Bipolar affective disorder
45

57

156

91

38
$66.7 \%$

0.041

$35.6 \%$

$42.1 \%$

$56.1 \%$

$46.1 \%$

$27.5 \%$

$<0.001$

$16.5 \%$

$<0.001$

$32.1 \%$

$73.7 \%$

$55.3 \%$ 
Table 1 - Cont.

\begin{tabular}{|c|c|c|c|c|c|}
\hline & \multirow[b]{2}{*}{$\mathbf{n}$} & \multicolumn{2}{|c|}{ Ideation } & \multicolumn{2}{|c|}{ Attempt } \\
\hline & & $(\%)$ & $\mathbf{p}^{*}$ & $(\%)$ & $\mathbf{p}^{*}$ \\
\hline Depression & 133 & $57.1 \%$ & & $42.9 \%$ & \\
\hline Mental retardation & 52 & $23.1 \%$ & & $21.1 \%$ & \\
\hline Other neurotic disorders & 30 & $56.7 \%$ & & $30 \%$ & \\
\hline Other unspecified disorders & 19 & $68.4 \%$ & & $42.1 \%$ & \\
\hline \multicolumn{6}{|l|}{ Hearing voices } \\
\hline Absent & 208 & $39.4 \%$ & $<0.001$ & $29.8 \%$ & 0.106 \\
\hline Present & 181 & $58.1 \%$ & & $37.7 \%$ & \\
\hline \multicolumn{6}{|l|}{ History of violence } \\
\hline Absent & 263 & $41.1 \%$ & $<0.001$ & $24.3 \%$ & $<0.001$ \\
\hline Present & 126 & $62.7 \%$ & & $52.4 \%$ & \\
\hline TOTAL & 389 & $48.1 \%$ & & $33.4 \%$ & \\
\hline
\end{tabular}

As for the attempted suicide, there was a statistically significant difference between the genders ( $p=0.007)$. The prevalence of this outcome among men was $25 \%$, however, among women, attempted suicides were present in 38.4\% of the cases studied.

As with suicidal ideation, there were no differences in the prevalence of attempted suicides in terms of age. However, a higher prevalence was found in users between 41 and 50 years old. On the other hand, there was a statistically significant difference regarding the marital status of the users $(p=0.002)$. Individuals who were separated or widowed had the highest prevalence (44.3\%) of attempted suicide.

Differently from what was observed about suicidal ideation, there were no statistically significant differences in the prevalence of attempted suicides in terms of schooling and source of income. However, it was also possible to observe significant statistical differences with regard to the diagnosis of users ( $p=<0.001$ ). The prevalence variation between diagnoses was $16.5 \%$ among schizophrenics and 55.3\% among individuals with bipolar affective disorder.

In contrast to the cases of suicidal ideation, it was not possible to observe statistical differences for the prevalence of attempted suicides in what concerns the phenomenon of listening to voices. Regarding exposure to violence, it was possible to observe statistically significant differences regarding the prevalence of this outcome $(p=<0.001)$. Among users who had a history of violence, the prevalence of attempted suicide was $52.4 \%$, while in users who did not report this type of situation, the prevalence was $24.3 \%$.

Regarding the interaction between suicidal ideation and attempted suicides, it was possible to observe that among those users who had reported the presence of suicidal ideation, the prevalence of attempted suicide was $57.7 \%$, while in users without a report of ideation, the record of attempted suicides was $10.9 \%(p=<0.001)$.

\section{DISCUSSION}

The relationship between suicidal ideation and attempted suicide is described as a strong risk factor for the occurrence of death by suicide. The meta-analysis carried out with 70 studies found a moderately strong and heterogeneous association between suicidal ideation and subsequent suicide $(\mathrm{OR}=3.41,95 \% \mathrm{Cl} 2.59-4.49)^{(8)}$. 
This study corroborates this finding by demonstrating that, among users who had suicidal ideation, in $57.7 \%$ of them there was also a prevalence of attempted suicides.

Globally, suicides account for $50 \%$ of violent deaths in men and $71 \%$ in women. In rich countries, men die about three times more from suicide than women. In middle or low-income countries, this ratio is lower, with 1.5 men for each woman. In relation to age, suicide rates are higher in people aged 70 or more for men and women in almost all regions ${ }^{(9)}$.

In Brazil, the profile of people who commit suicide varies according to schooling, race/color, gender and age, being the most affected: indigenous people, people with low education, men and over 60 years old, with important regional differences in mortality by suicide. The highest mortality is found in the South (9.8/100 thousand) and the highest percentage growth in the Northeast (72.4\%). Although over the past 13 years there has been an increase in mortality from suicide, the South and Midwest regions have their rates decreasing ${ }^{(10)}$.

Between 1996 and 2015,172,051 suicide deaths were recorded in Brazil, with the lowest number of cases occurring in the North region (1,714 cases), in the period 1996-2000, while the highest number occurred in the Southeast region $(20,467$ cases), in the period 2011-2015(10).

In the State of Rio Grande do Sul, in 2016,1,166 deaths from suicide were recorded, which is equivalent to the rate of 11.0 per 100 thousand inhabitants, 17.8 for men and 4.5 for women, which is characterized by approximately twice the Brazilian rate. In the same period,3,700 cases of self-harm violence were reported. From these, 1,837 were classified as attempted suicide, which is equivalent to a rate of 17.4 per 100 thousand inhabitants and this varies significantly among the 30 Health Regions in Rio Grande do Sul(11).

A study carried out in a CAPSIII identified a prevalence of suicidal behavior of $38.7 \%$ for women and $31.8 \%$ for men; greater suicidal ideation among women (28.1\%) and greater suicide attempt among men (23.7\%) $)^{(12)}$. Among health students, the prevalence of ideation is $22 \%$ and higher among men ${ }^{(13)}$. The prevalence of suicidal ideation in the last 300 days among family members who care for people in psychological distress and who attend Psychosocial Care Centers in the southern region of Brazil was $12.5 \%{ }^{(14)}$.

A comparison can be made with this study in which it was seen that the prevalence of suicidal ideation was 39.6\% in men and $53.1 \%$ in women, as well as what was found in the above-mentioned study, in which suicidal ideation was more prevalent in women. Regarding the prevalence of attempted suicides, there is a higher rate in women (38.4\%).

A study carried out in Brazil, analyzing data from the Mortality Information System (MIS) and DATASUS, found the male prevalence in suicide rates, which is associated with alcohol consumption. It was observed that the risk increases in the female population, when women are unemployed, with low educational level and low income. Psychiatric diagnoses associated with suicide vary in relation to gender, with schizophrenia being the most prevalent diagnosis among men and, in women, the use of psychoactive substances ${ }^{(15)}$.

In this study, the diagnosis that relates to most cases of suicidal ideation consists of bipolar affective disorder and, in cases of attempt, the same diagnosis prevails.

A cross-sectional study carried out with 253 patients in Alagoas ${ }^{(12)}$ observed that the presence of current depression increases the risk of suicide by more than six times, compared to those who do not have this disorder, with this risk being moderate to severe among nephropaths/cardiopaths. The presence of Generalized Anxiety Disorder has been shown to be associated with a risk of suicide four times greater than that of the population without the disorder, tending to be of mild severity among the nephropaths/cardiopaths investigated.

Regarding gender, the total number of deaths due to self-extermination in men was three times higher than in women. It was noticed less occurrence of the consummated act of self-extermination among women, which can be attributed to the low incidence of alcoholism, religiosity, more flexible attitudes towards social problems, among others. In addition, women perceive early signs of risk for mental illnesses and seek more help in facing the situations experienced ${ }^{(4)}$.

Equally, it is verified that attempted suicides occur more frequently in females, because, in males, is more effective suicide consummated by the use of more lethal means ${ }^{(16)}$. This is confirmed in this study, in which were seen attempted suicides rates of $38.4 \%$ in females and $25 \%$ in males.

Regarding the age group, a study that evaluated 89 cases of attempted suicides due to exogenous intoxication, the age group with the highest occurrence of attempts was 20 to 29 years old, with 25 cases (28.1\%), followed by 15 to 19 years old, with 17 cases (19.0\%), the majority being women, with 68 cases (76.4\%). A higher incidence of suicide attempt was found in the female population aged 15 to 19 years, with 49.6 cases $^{(17)}$.

In this research, the age group that most concentrated the cases of ideation and attempted suicide was between 41 and 50 years old, with no significant difference between genders.

A study that characterized attempted suicide and suicides that occurred in a municipality in the northwest of the State of Paraná, attended in a pre-hospital service carried out with 257 people, between 2005 and 2012, found that the possible aggravating factors for the occurrence of attempted suicide 
and suicide were neurological and psychological disorders in $48.9 \%$ and ethyl breath/use of illicit drugs in $41.9 \%$ of occurrences. The presence of neurological/psychological disorders was the aggravating factor with the highest percentage of occurrence among women (64.3\%) and ethyl breath/use of illicit drugs, the most found in males $(61.8 \%)^{(18)}$.

About the experience of lived violence, a study found that, from its 628 participants, $26.1 \%(n=164)$ suffered verbal violence, followed by psychological or moral violence $(21.3 \%=34)$, physical violence $(8,1 \%=51)$ and sexual violence $(2.0 \%=12)^{(19)}$.

In this study, regarding the association of ideation and attempted suicide with violence, it was observed that, from the users who had suicidal ideation, $62.7 \%$ of them had suffered some type of violence and, in those who attempted suicide, the prevalence of violence was present in 52.4\% of users, corroborating that there is a relevant relationship between ideation and attempted suicide in users suffering from some type of violence.

The study that evaluated three groups of participants in a larger study ${ }^{(20)}$ (who had already attempted suicide, who had suicidal ideas, but never tried and another group that had never had either ideation or attempt) found that, in relation to situations of violence, both the presence of family violence and community violence differentiated the group without ideation or attempt with the other groups, which had higher rates, demonstrating the experience of violence.

\section{aCONCLUSIONS}

It was found information of great relevance in this article, enabling the identification and characterization of the prevalence of ideation and attempted suicide. Based on these results, the study points to contributions to assistance, as it can be seen that preventive measures based on care for adult users between 40 and 50 years old, divorced and/or widowed can corroborate the reduction of suicidal ideations, requiring further attention especially when they are female users, who had both ideation and attempted suicide, in a much higher number than male users.

Another important aspect is that the idea of suicide is more prevalent in users who have a higher degree of study and paid work, demonstrating that what is seen by society as a requirement for a successful life are factors that seem to predispose to suicidal practices. However, when analyzing the attempt, no significant differences were found based on these variables.

People with some mental retardation showed a predisposition to suicidal ideation when compared to those who do not have any disorder, being bipolar affective disorder what seems to make people more susceptible, repeating this information when referring to the prevalence of the attempt.

Users from the studied mental health service, who hear voices that others do not hear, have a significant prevalence of suicidal ideation, a fact that deserves further studies in this regard in order to reveal the associated factors, since it could be a reflex from the negative voices and from command influencing this issue. However, regarding the attempted suicide, no significant differences were observed, demonstrating that the listeners, although they think or are led to think more about the possibility of taking their own life, do not put it into practice more than the others.

It should be given due attention to the violence variable, since it has been shown that suicidal ideations are more prevalent in users who have reported any situation of this type and it is also significant the number who attempted suicide having reported some situation of violence. This allows to see how much violence, in addition to the obvious consequences of the act itself, permeates the core of the mind with a lot of a posteriori suffering, with the ability to lead individuals to commit cruel acts against themselves.

Regarding contributions to teaching and research, the importance of studies such as this one in obtaining information about users' ideation and attempted suicide is highlighted, bringing to health professionals and society in general, tools that help in the identification of potential suicides. As this public health issue is problematized, it can be brought up for discussion in the various devices of society, including the university, addressing intervention strategies and spaces for listening and welcoming, as well as new studies on the subject. This can be a differential to save lives and take actions aimed at prevention, preventing lives from being cut early and promoting well-being and health.

\section{REFERENCES}

1. World Health Organization (CH). Preventing suicide: a global imperative. Geneva: WHO; 2014 [cited 2019 Sep 10]. Available from: https://www.who. int/mental_health/suicide-prevention/world_report_2014/en/

2. Freitas MNV, Seiwald MCN, Parada RA, Huvner CK. Suicídio consumado na cidade de Sorocaba-SP: um estudo epidemiológico. Rev Fac Cienc Med Sorocaba. 2013 [cited 2019 Sep 10];15(3):53-8. Available from: https://revistas.pucsp.br/ RFCMS/article/view/9925/pdf

3. Thesolim BL, Bernardino A, Ferreira VL, Baptista CA, Franco LFR. Suicídios em município do interior de São Paulo: caracterização e prevalência de gêneros. Rev Bras Multidiscipl. 2016;19(1):139-46. doi: https://doi.org/10.25061/25272675/ReBraM/2016.v19i1.372

4. Vieira VAS, D'Alessandro FCS, Silva FMR, Coelho KR, Quadros KAN. Characterization of the individuals who executed and/or attempted selfextermination in Itapecerica, Minas Gerais, Brazil. Rev Enferm Centro-0 Min. 2017;7:e1681. doi: https://doi.org/10.19175/recom.v7i0.1681 
5. Rendón-Quintero E, Rodríguez-Gómez R. Vivencias y experiencias de individuos con ideación e intento suicida. Rev Colomb Psiquiatr. 2016;45(2):92-100. doi: https://doi.org/10.1016/j.rcp.2015.08.003

6. Ministério da Saúde (BR), Secretaria de Atenção à Saúde, Departamento de Ações Programáticas Estratégicas. Agenda de ações estratégicas para a vigilância e prevenção do suicídio e promoção da saúde no Brasil: 2017-2020. Brasília, DF: Ministério da Saúde; 2017 [cited 2019 Sep 10]. Available from: https://www. neca.org.br/wp-content/uploads/cartilha_agenda-estrategica-publicada.pdf

7. Cescon LF, Capozzolo AA, Lima CL. Aproximações e distanciamentos ao suicídio: analisadores de um serviço de atenção psicossocial. Saúde Soc. 2018;27(1):185200. doi: https://doi.org/10.1590/S0104-12902018170376

8. McHugh MC, Amy C, Ryan JC, Hickie Bl. Large MM. Association between suicidal ideation and suicide: meta-analyses of odds ratios, sensitivity, specificity and positive predictive value. BJPsych Open. 2019:5(2):e18. doi: https://doi. org/10.1192/bjo.2018.88

9. Machado DB, Santos DN. Suicídio no Brasil, de 2000 a 2012. J Bras Psiquiatr. 2015;64(1):45-54. doi: https://doi.org/10.1590/0047-2085000000056

10. D'Eça Júnior A, Rodrigues LSR, Meneses Filho EP, Costa LDNC, Rêgo ASR, Costa LC, et al. Mortalidade por suicídio na população brasileira, 1996-2015: qual é a tendência predominante. Cad Saúde Colet. 2019;27(1):20-4. doi: https://doi. org/10.1590/1414-462x201900010211

11. Boletim de Vigilância Epidemiológica de Suicídio e Tentativa de Suicídio. Bol Vig Suicídio. 2018 [cited 2019 Sep 10];1(1):1-8. Available from: https://www. cevs.rs.gov.br/upload/arquivos/201809/05162957-boletim-de-vigilanciaepidemiologica-de-suicidio-n1-2018.pdf

12. Botti NCL, Cantão L, Silva AC, Gonçalves Dias TG, Menezes $L C$, et al. Characteristics and risk factors for suicidal behavior among men and women with psychiatric disorders. Cogitare Enferm. 2018;23(2):e54280. doi: https:// doi.org/10.5380/ce.v23i1.54280
13. Vasconcelos JRO, Lôbo APS, Melo VL Neto. Risco de suicídio e comorbidades psiquiátricas no transtorno de ansiedade generalizada. J Bras Psiquiatr. 2015; 64(4):259-65. doi: https://doi.org/10.1590/0047-2085000000087

14. Veloso LUP, Lima CLS, Sales JCS, Monteiro CFS, Gonçalves AMS, Silva Júnior FJG. Suicidal ideation among health field undergraduates: prevalence and associated factors. Rev Gaúcha Enferm. 2019;40:e20180144. doi: https://doi. org/10.1590/1983-1447.2019.20180144

15. Treichel $C A D$, Jardim VMD, Kantorski $L P$, Lima MG. Prevalence and factors associated with suicidal ideation among family caregivers of people with mental disorders. J Clin Nurs. 2019;28(19-20):3470-7. doi: https://doi.org/10. 1111/jocn. 14938

16. Fernandes DAA, Ferreira NS, Castro JGD. Epidemiological profile of suicide attempts in Palmas- Tocantins, 2010-2014. Tempus, Actas Saúde Colet. 2016;10(4):9-23. doi: https://doi.org/10.18569/tempus.v11i1.2016

17. Ribeiro NM, Castro SS, Scatena LM, Haas VJ. Time-trend analysis of suicide and of health information systems in relation to suicide attempts. Texto Contexto Enferm, 2018;27(2):e2110016. doi: https://doi.org/10.1590/0104-07072018 0002110016

18. Rosa NM, Agnolo CMD, Oliveira RR, Mathias TAF, Oliveira MLF. Tentativas de suicídio e suicídios na atenção pré-hospitalar. J Bras Psiquiatr. 2016;65(3):231-8. doi: https://doi.org/10.1590/0047-2085000000129

19. Ribeiro MMR, Tavares R, Melo EMM, Bonolo PF, Melo VH. Promoção de saúde, participação em ações coletivas e situação de violência entre usuários da Atenção Primária à Saúde. Saúde Debate. 2018;42(4):43-54. doi: https://doi. org/10.1590/0103-11042018s403

20. Pereira AS, Willhelm AR, Koller SH, Almeida RMM. Risk and protective factors for suicide attempt in emerging adulthood. Ciênc Saúde Coletiva. 2018;23(11):3767-77. doi: https://doi.org/10.1590/1413-812320182311.29 112016 
- Acknowledgments:

To the National Council for Scientific and Technological Development (Conselho Nacional de Desenvolvimento Científico e Tecnológico - CNPq).

\section{- Authorship contribution:}

Conceptualization: Luciane Prado Kantorski.

Data curation: Luciane Prado Kantorski.

Formal Analysis: Luciane Prado Kantorski.

Funding acquisition: Luciane Prado Kantorski

Investigation: Luciane Prado Kantorski.

Methodology: Luciane Prado Kantorski, Vanda Maria da Rosa Jardim

Project administration: Luciane Prado Kantorski

Resources: Luciane Prado Kantorski.

Software: Vanda Maria da Rosa Jardim, Carlos Alberto dos Santos Treichel, Camila Irigonhé Ramos.

Supervision: Luciane Prado Kantorski, Vanda Maria da Rosa Jardim, Ariane da Cruz Guedes, Janaína Quinzen Willrich.

Validation: Luciane Prado Kantorski, Vanda Maria da Rosa Jardim.

Visualization: Luciane Prado Kantorski.

Writing - original draft: Carlos Alberto dos Santos Treichel, Camila Irigonhé Ramos, Vinícius Boldt dos Santos, Dariane Lima Portela.

Writing - review \& editing: Luciane Prado Kantorski, Vanda Maria da Rosa Jardim, Ariane da Cruz Guedes, Janaína Quinzen Willrich. Carlos Alberto dos Santos Treichel, Camila Irigonhé Ramos, Vinícius Boldt dos Santos, Dariane Lima Portela.

\section{- Corresponding author:}

Vinícius Boldt dos Santos

E-mail:Vini_boldt@yahoo.com.br

Associate editor:

Cíntia Nas

Maria da Graça Oliveira Crossetti 